\title{
Different Designs of Dual-Focus Perforated Transmitarray Antenna in Near/Far- Field Region
}

\author{
S.H. Zainud-Deen ${ }^{1}$, W. M. Hassan ${ }^{2 *}$, and H.A. Malhat ${ }^{1 * *}$ \\ ${ }^{1}$ Faculty of Electronic Eng., Menoufia University, Egypt \\ ${ }^{2}$ Electronics Research Institute, Giza, Egypt \\ *walaa81hassan@yahoo.com,**er_honida1@yahoo.com
}

\begin{abstract}
In this paper, the design of single-focused and dual-focused transmitarray antennas in the near-field (NF) or/and far-field (FF) applications are proposed. A unit-cell element consists of a dielectric square box with four identical holes is used. The phase compensation of the unit-cell elements depends on changing the hole radii according to the position of the unit-cell element, the feeding horn, and the beam direction. The radiation characteristics of $13 \times 13$ unit-cell elements transmitarray antenna focused in the near- and the far-field regions are investigated. A single structure, dual-focused transmitarray is designed using a chess-board arrangement of the unit-cell elements. Double-focused transmitarray antennas for FF/FF, FF/NF, and NF/NF are designed and investigated. The phase distributions and the corresponding hole radii for different configurations of the dual-focused transmitarray antennas are presented. The radiation characteristics of different array configurations are investigated and analyzed using a full-wave simulator CST Microwave Studio.
\end{abstract}

\section{Introduction}

One of the major trends in antenna design is to enhance antenna gain for a variety of applications. Different types of high gain antennas such as, parabolic reflector, dielectric lens, and phased array are investigated [1]. These antennas provide high gain radiation characteristics, however, these antennas are bulky, heavy, and need complex feeding networks $[2,3]$. The reflectarray and transmitarray antennas are safe alternatives to parabolic reflectors and lenses because of their planar low profile, simple manufacturing process, and low cost especially for beam shaping applications $[4,5]$. The transmitarray antenna consists of unit-cell elements arranged in a planar structure, and is illuminated by an incident wave from horn antenna. The antenna unit-cell elements are tuned in order to collimate the transmitted wave in a directed focused beam [6]. Different methods that used to control the phase compensation of the transmitarray elements are discussed in details in [7-9]. The radiation characteristics of different transmitarray designs using dipoles, microstrip patch, and dielectric resonator antenna are investigated in [10-14]. Multifocal optical lenses are artificial lenses designed to provide simultaneous focus at different distances in contrast to mono-focal lenses which only one focal point [15]. Focused beam systems are borrowed from optics such as spherical optical lenses. Nearfield focused transmitarray antenna is a good choice for many applications due to low profile, low cost, and compact structure. Near-field focused transmitarray transforms the incident plane wave into a spherical wave that focused at a focal point [16]. The design of the near-field (NF) focused antenna is based on tuning the phase of the field, along the aperture of the antenna in order to obtain a locally plane wavefront at a focal point [17]. NF-focused antennas have different applications such as microwave remote sensing, and medical application [18, 19]. NF-focused microstrip arrays are designed for gate-access control and industrial heating [20, 21]. Radio-frequency identification (RFID) are introduced as a proper application for NF-focused antennas for fixed readers [22-24].

In this paper, a dual-focused transmitarray antennas with different focal locations are introduced using a single structure. The unit-cell element consists of a perforated dielectric box with identical four holes. Double-focused transmitarrays in the far-field and near-field regions are presented. The chess-board unit-cell element arrangement is applied for dual-focused transmitarray design. The radiation characteristics of different transmitarray configurations are analyzed using (Computer Simulation Technology) Microwave Studio CST [25].

\section{Theory and design of transmitarray antenna}

\subsection{Transmitarray unit-cell element design}

The shape of the perforated dielectric unit-cell element for transmitarray antenna design has been introduced in [26] as shown in Fig. 1a. The unit-cell element consists of a square dielectric box, with an arm length $\mathrm{L}=15 \mathrm{~mm}$, thickness $\mathrm{h}=$ $15 \mathrm{~mm}$, and dielectric constant, $\varepsilon_{\mathrm{r}}=12$ (HiK500F material). Each unit-cell element has four identical circular holes with radius $r$. The required phase compensation of each unit-cell element is achieved by varying the hole radius, using the waveguide simulator model [26]. The waveguide simulator is excited by a normal incidence plane wave for simplicity (This premise holds for incident plane wave with oblique angle up to 40 points). The variations of the transmission coefficient phase and magnitude versus the hole radius, $r$, at $10 \mathrm{GHz}$ are shown in Fig. 1b. The transmission coefficient phase variation from 0 to 340 degrees with transmission 
coefficient magnitude variation from 0 to $-5.3 \mathrm{~dB}$ is achieved. The hole radius changed from 0.2 to $3.75 \mathrm{~mm}$. The results are calculated using the CST software and are compared with that calculated using High Frequency Structural Simulator (HFSS). Satisfactory agreement between results is obtained.
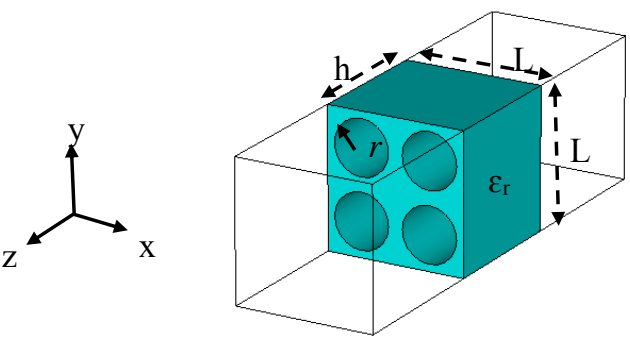

(a)

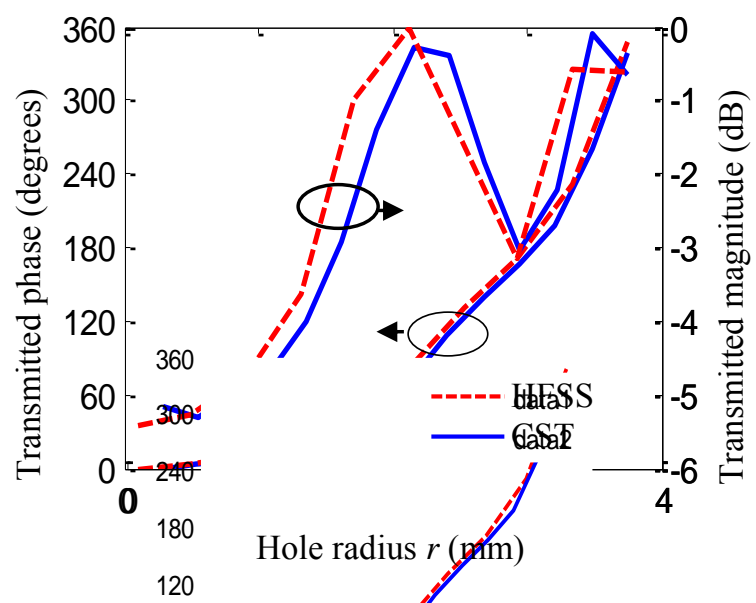

Figure 1: (a) Trabos GHz. (b) The var magnitude with hol@radiust at $10 \mathrm{GHz}$.

lesign at 10 phase and 4

\subsection{FF-NF-focused transmitarray antenna}

The transmitarray is considered as a 2-D planar array with spatial feeding horn with its aperture located at $\left(x_{f}, y_{f}, z_{f}\right)$. The phase of each unit-cell element depends on its position in the array $\left(x_{i j}, y_{i j}\right)$, the direction of the transmitted beam $\left(\theta_{o}, \emptyset_{o}\right)$, and is given by:

$\varphi_{i j}\left(x_{i j}, y_{i j}\right)=k_{o}\left[\begin{array}{c}d_{i j}-x_{i j} \sin \left(\theta_{o}\right) \cos \left(\emptyset_{o}\right) \\ -y_{i j} \sin \left(\theta_{o}\right) \sin \left(\emptyset_{o}\right)\end{array}\right]$,

$d_{i j}=\sqrt{\left(x_{i j}-x_{f}\right)^{2}+\left(y_{i j}-y_{f}\right)^{2}+z_{f}^{2}}$,

where $k_{o}$ is the propagation constant, $d_{i j}$ is the distance from the feed point to the $i j^{\text {th }}$ element in the array. The NFfocusing is achieved by adding an extra phase to the unit-cell elements to collimate the beam at a focal point at a distance $\mathrm{R}_{\mathrm{o}}$ from the array aperture as shown in Fig.2. The extra phase shift of the $i j^{\text {th }}$ element in the NF-focused transmitarray is calculated from [27], $\emptyset_{i j N F}=k_{o}\left(\sqrt{x_{i j}^{2}+y_{i j}^{2}+R_{o}^{2}}-R_{o}\right)$,

The total phase for the NF-focus array is obtained by adding Eq. 1 to Eq. 3 for each unit-cell element. The design of $13 \times 13$ unit-cell elements perforated transmitarray with total area of $195 \times 195 \mathrm{~mm}^{2}$ to collimate field at far-field (FF) at $10 \mathrm{GHz}$ applications is shown in Fig. 3 . The design of $13 \times 13$ unitcell elements perforated transmitarray with the same area to collimate field at near-field (NF) is shown in Fig. 4. A linearly polarized horn antenna is used to feed the transmitarray with dimensions $R_{i}=25 \mathrm{~mm}, l_{i} \times w_{i}=$ $11.4 \times 22.8 \mathrm{~mm}^{2}$ and thickness $t=0.6 \mathrm{~mm}$. The horn antenna is placed at a distance $\mathrm{F}=175.5 \mathrm{~mm}$ from the transmitarray aperture. The transmitarray has a symmetric configuration. The phases and values of holes radii are symmetric. The phase distribution on the first quadrant of the FF-focused transmitarray and the NF-focused transmitarray at $\mathrm{R}_{\mathrm{o}}=310$ $\mathrm{mm}$ with the corresponding hole radii are listed in Table 1.

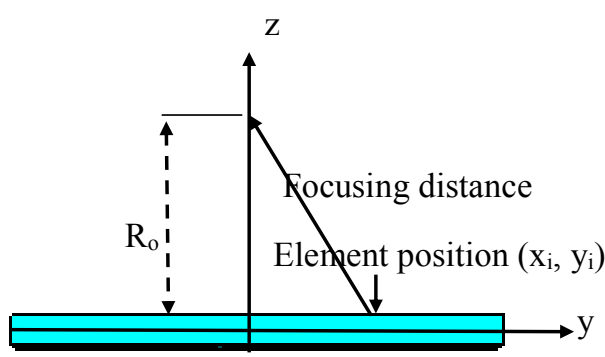

Figure 2: The NF focused at a distance $z=R_{0}$ from the transmitarray aperture.

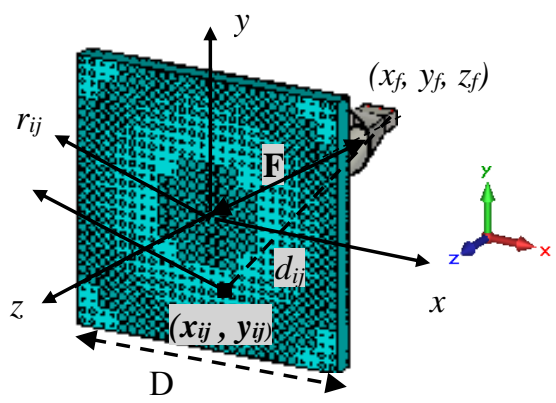

Figure 3: The detailed construction of the configuration $13 \times 13$ FF-focused transmitarray.

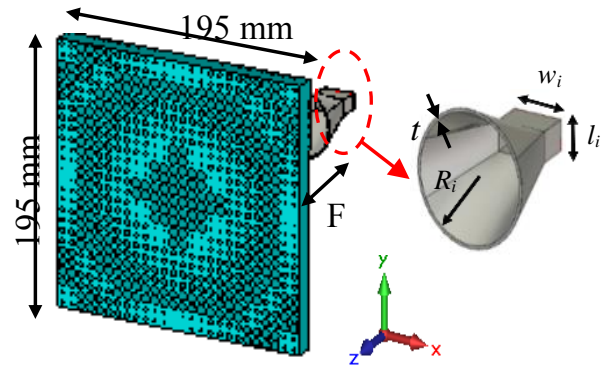

Figure 4: The 3-D detailed construction of the configuration $13 \times 13$ NF focused transmitarray. 
Table 1: The phase shift and the corresponding hole radius for FF and NF transmitarray (first quadrant).

a. NF-focused transmitarray

\begin{tabular}{|c|c|c|c|c|c|c|}
\hline $306^{\circ}$ & $313.67^{\circ}$ & $336.54^{\circ}$ & $14.12^{\circ}$ & $65.67^{\circ}$ & $130.24^{\circ}$ & $206.77^{\circ}$ \\
$3.64 \mathrm{~mm}$ & $3.66 \mathrm{~mm}$ & $3.74 \mathrm{~mm}$ & $1.17 \mathrm{~mm}$ & $2.06 \mathrm{~mm}$ & $2.58 \mathrm{~mm}$ & $3.26 \mathrm{~mm}$ \\
\hline $313.67^{\circ}$ & $321.32^{\circ}$ & $344.11^{\circ}$ & $21.56^{\circ}$ & $72.94^{\circ}$ & $137.31^{\circ}$ & $213.61^{\circ}$ \\
$3.66 \mathrm{~mm}$ & $3.69 \mathrm{~mm}$ & $3.74 \mathrm{~mm}$ & $1.39 \mathrm{~mm}$ & $2.12 \mathrm{~mm}$ & $2.64 \mathrm{~mm}$ & $3.29 \mathrm{~mm}^{\circ}$ \\
\hline $336.54^{\circ}$ & $344.11^{\circ}$ & $6.66^{\circ}$ & $43.73^{\circ}$ & $94.60^{\circ}$ & $158.36^{\circ}$ & $234^{\circ}$ \\
$3.74 \mathrm{~mm}$ & $3.74 \mathrm{~mm}$ & $0.76 \mathrm{~mm}$ & $1.82 \mathrm{~mm}$ & $2.3 \mathrm{~mm}$ & $2.85 \mathrm{~mm}$ & $3.38 \mathrm{~mm}$ \\
\hline $14.12^{\circ}$ & $21.56^{\circ}$ & $43.73^{\circ}$ & $80.18^{\circ}$ & $130.24^{\circ}$ & $193.04^{\circ}$ & $267.59^{\circ}$ \\
$1.17 \mathrm{~mm}$ & $1.39 \mathrm{~mm}$ & $1.82 \mathrm{~mm}$ & $2.19 \mathrm{~mm}$ & $2.58 \mathrm{~mm}$ & $3.18 \mathrm{~mm}$ & $3.5 \mathrm{~mm}$ \\
\hline $65.67^{\circ}$ & $72.94^{\circ}$ & $94.60^{\circ}$ & $130.24^{\circ}$ & $179.23^{\circ}$ & $240.75^{\circ}$ & $313.87^{\circ}$ \\
$2.06 \mathrm{~mm}$ & $2.12 \mathrm{~mm}$ & $2.3 \mathrm{~mm}$ & $2.58 \mathrm{~mm}$ & $3.06 \mathrm{~mm}$ & $3.40 \mathrm{~mm}$ & $3.66 \mathrm{~mm}$ \\
\hline $130.24^{\circ}$ & $137.31^{\circ}$ & $158.36^{\circ}$ & $193.04^{\circ}$ & $240.75^{\circ}$ & $300.73^{\circ}$ & $12.12^{\circ}$ \\
$2.58 \mathrm{~mm}$ & $2.64 \mathrm{~mm}$ & $2.85 \mathrm{~mm}$ & $3.18 \mathrm{~mm}$ & $3.4 \mathrm{~mm}$ & $3.62 \mathrm{~mm}$ & $1.1 \mathrm{~mm}$ \\
\hline $206.77^{\circ}$ & $213.61^{\circ}$ & $234^{\circ}$ & $267.59^{\circ}$ & $313.87^{\circ}$ & $12.12^{\circ}$ & $81.54^{\circ}$ \\
$3.26 \mathrm{~mm}$ & $3.29 \mathrm{~mm}$ & $3.38 \mathrm{~mm}$ & $3.5 \mathrm{~mm}$ & $3.66 \mathrm{~mm}$ & $1.1 \mathrm{~mm}$ & $2.2 \mathrm{~mm}$ \\
\hline
\end{tabular}

b. FF-focused transmitarray.

\begin{tabular}{|c|c|c|c|c|c|c|}
\hline $306^{\circ}$ & $318.03^{\circ}$ & $353.92^{\circ}$ & $53.11^{\circ}$ & $134.71^{\circ}$ & $2.37 .57^{\circ}$ & $360.38^{\circ}$ \\
$3.64 \mathrm{~mm}$ & $3.68 \mathrm{~mm}$ & $3.74 \mathrm{~mm}$ & $1.94 \mathrm{~mm}$ & $2.62 \mathrm{~mm}$ & $3.39 \mathrm{~mm}$ & $0.26 \mathrm{~mm}$ \\
\hline $318.03^{\circ}$ & $330.02^{\circ}$ & $365.82^{\circ}$ & $64.86^{\circ}$ & $146.25^{\circ}$ & $248.86^{\circ}$ & $371.39^{\circ}$ \\
$3.68 \mathrm{~mm}$ & $3.72 \mathrm{~mm}$ & $0.69 \mathrm{~mm}$ & $2.05 \mathrm{~mm}$ & $2.73 \mathrm{~mm}$ & $3.43 \mathrm{~mm}$ & $1.06 \mathrm{~mm}$ \\
\hline $353.92^{\circ}$ & $365.82^{\circ}$ & $41.34^{\circ}$ & $99.92^{\circ}$ & $180.70^{\circ}$ & $282.58^{\circ}$ & $404.29^{\circ}$ \\
$3.74 \mathrm{~mm}$ & $0.69 \mathrm{~mm}$ & $1.79 \mathrm{~mm}$ & $2.34 \mathrm{~mm}$ & $3.06 \mathrm{~mm}$ & $3.56 \mathrm{~mm}$ & $1.83 \mathrm{~mm}$ \\
\hline $53.11^{\circ}$ & $64.86^{\circ}$ & $99.92^{\circ}$ & $157.76^{\circ}$ & $237.57^{\circ}$ & $338.27^{\circ}$ & $458.66^{\circ}$ \\
$1.94 \mathrm{~mm}$ & $2.05 \mathrm{~mm}$ & $2.34 \mathrm{~mm}$ & $2.84 \mathrm{~mm}$ & $3.39 \mathrm{~mm}$ & $3.74 \mathrm{~mm}$ & $2.33 \mathrm{~mm}$ \\
\hline $134.71^{\circ}$ & $146.25^{\circ}$ & $180.70^{\circ}$ & $237.57^{\circ}$ & $316.07^{\circ}$ & $415.21^{\circ}$ & $533.81^{\circ}$ \\
$2.62 \mathrm{~mm}$ & $2.73 \mathrm{~mm}$ & $3.06 \mathrm{~mm}$ & $3.39 \mathrm{~mm}$ & $3.67 \mathrm{~mm}$ & $1.96 \mathrm{~mm}$ & $3 \mathrm{~mm}$ \\
\hline $237.57^{\circ}$ & $248.86^{\circ}$ & $282.58^{\circ}$ & $338.27^{\circ}$ & $415.21^{\circ}$ & $512.45^{\circ}$ & $268.9^{\circ}$ \\
$3.39 \mathrm{~mm}$ & $3.43 \mathrm{~mm}$ & $3.56 \mathrm{~mm}$ & $3.74 \mathrm{~mm}$ & $1.96 \mathrm{~mm}$ & $2.79 \mathrm{~mm}$ & $3.51 \mathrm{~mm}$ \\
\hline $360.38^{\circ}$ & $371.39^{\circ}$ & $404.29^{\circ}$ & $458.66^{\circ}$ & $533.81^{\circ}$ & $268.90^{\circ}$ & $382.88^{\circ}$ \\
$0.26 \mathrm{~mm}$ & $1.06 \mathrm{~mm}$ & $1.83 \mathrm{~mm}$ & $2.33 \mathrm{~mm}$ & $3 \mathrm{~mm}$ & $3.51 \mathrm{~mm}$ & $1.42 \mathrm{~mm}$ \\
\hline
\end{tabular}

The E-plane and H-plane radiation patterns are presented in Fig. 5. The FF-focused transmitarray introduces a maximum gain of $23.45 \mathrm{~dB}$ compared to $17.26 \mathrm{~dB}$ for the NF-focused transmitarray. The maximum gain is reduced for the NFfocused transmitarray due to the collimating of the radiated power in the NF. The side lobe level (SLL) is $-15.7 \mathrm{~dB} /-18.6$ $\mathrm{dB}$ with half-power beamwidth (HPBW) of 7.6/8.3 degrees in the E-plane/H-plane for the FF-focused transmitarray. The side lobe level (SLL) is $-8 \mathrm{~dB} /-8 \mathrm{~dB}$ with half-power beamwidth (HPBW) of 11.9/11.7 degrees in the E-plane/Hplane for the NF-focused transmitarray. A wider beam is obtained in the far-field for the NF-focused transmitarray due to the concentration of power in the near-field. The normalized NF power density distribution along the focal plane at $\mathrm{R}_{\mathrm{o}}=310 \mathrm{~mm}$ for the FF- focused transmitarray and the NF-focused transmitarray in $\mathrm{x}-\mathrm{y}$ plane are indicated in Fig. 6. The contours of the power density are closer to each other for the NF-focused array with $-10 \mathrm{~dB}$ spot area $54 \mathrm{~mm}$ $\times 49 \mathrm{~mm}$ compared to the larger separation between the contours for the FF array with $-10 \mathrm{~dB}$ spot size of $99 \mathrm{~mm} \times$ $96 \mathrm{~mm}$. Figure 7 shows the distribution of the normalized power density along the $\mathrm{x}$-axis and $\mathrm{y}$-axis at the distance $\mathrm{R}_{\mathrm{o}}$ for the FF-focused transmitarray and the NF-focused transmitarray. The contour curves show that the field amplitude of the power density decays more slowly in the case of FF-focused transmitarray than that for the NFfocused transmitarray.

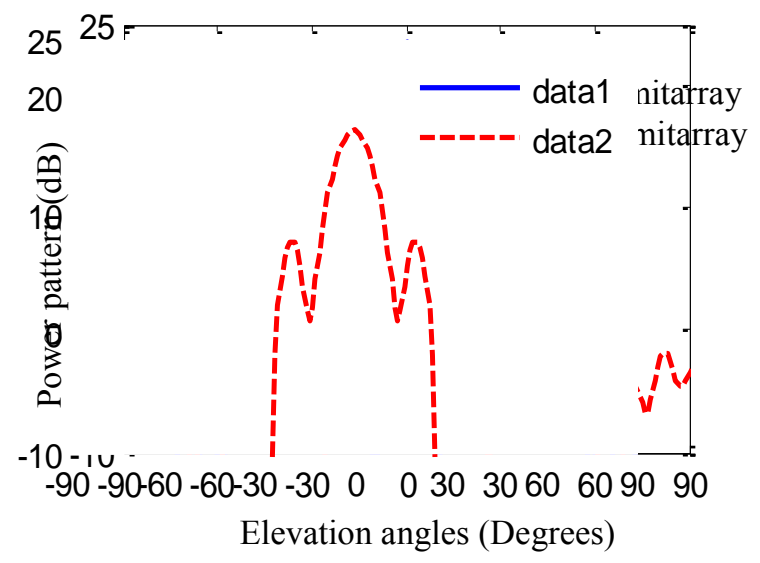

(a) E-plane 


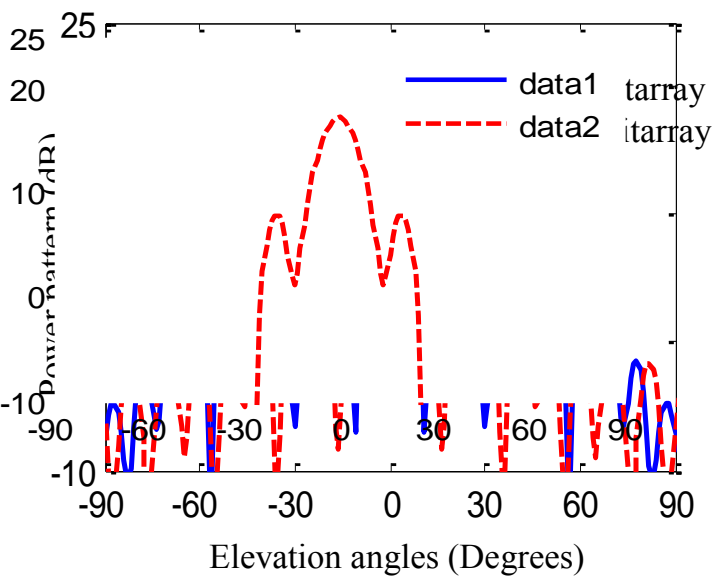

(b) H-plane
25

20

10

0

Figure 5: The E-plane and H-plane radiation patterns variations versus the elevation angle for configuration $13 \mathrm{kQ} 3$ FF focused transmitarray and $13 \times 13 \mathrm{NF}$ focused transmitarray at $\mathrm{F} / \mathrm{D}=0.9$ and frequency $10 \mathrm{GHz}$.

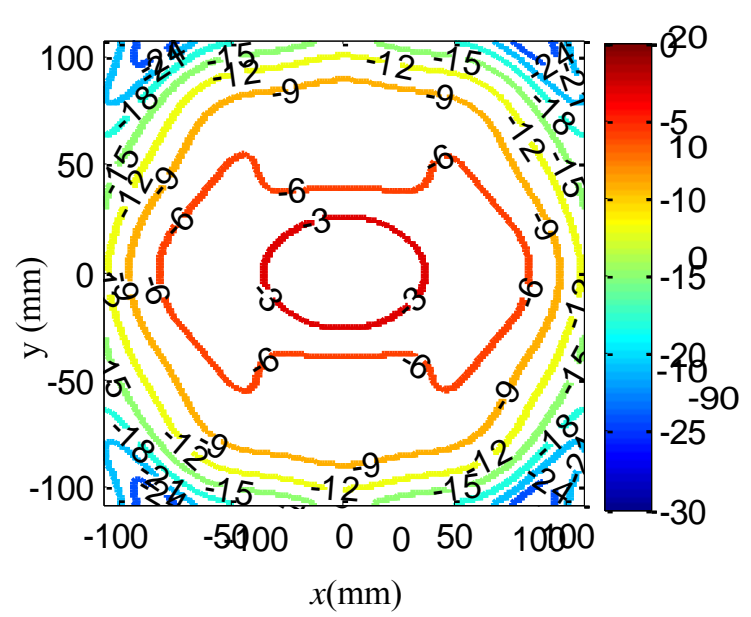

(a) FF-focused transmitarray

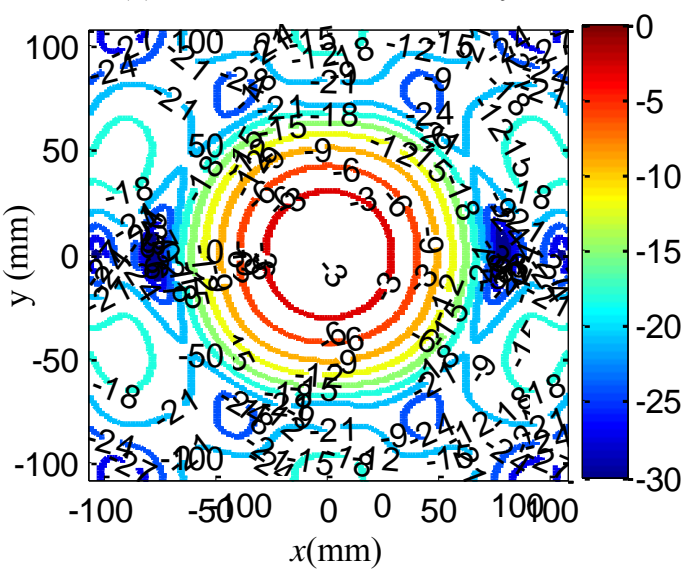

(b) NF-focused transmitarray

Figure 6: A contour plot of the simulated normalized power density of the $13 \times 13$ transmitarray in in $x-y$ plane for both FF- focused transmitarray and NF-focused transmitarray at $\mathrm{R}_{\mathrm{o}}=310 \mathrm{~mm}$.

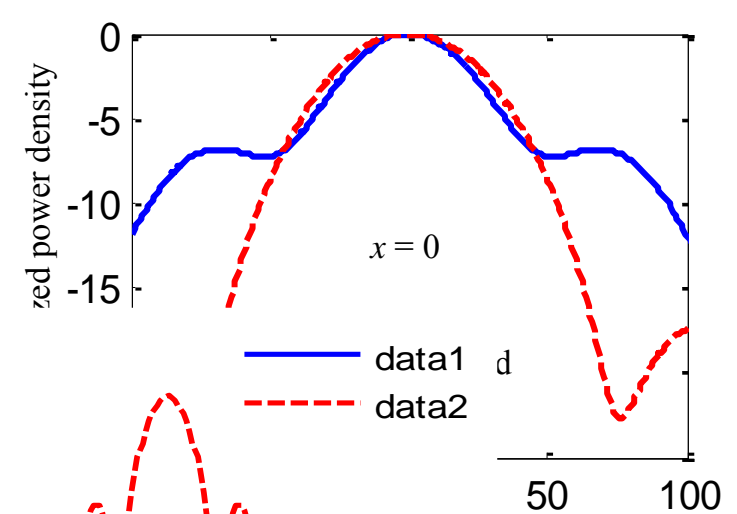

$-60$
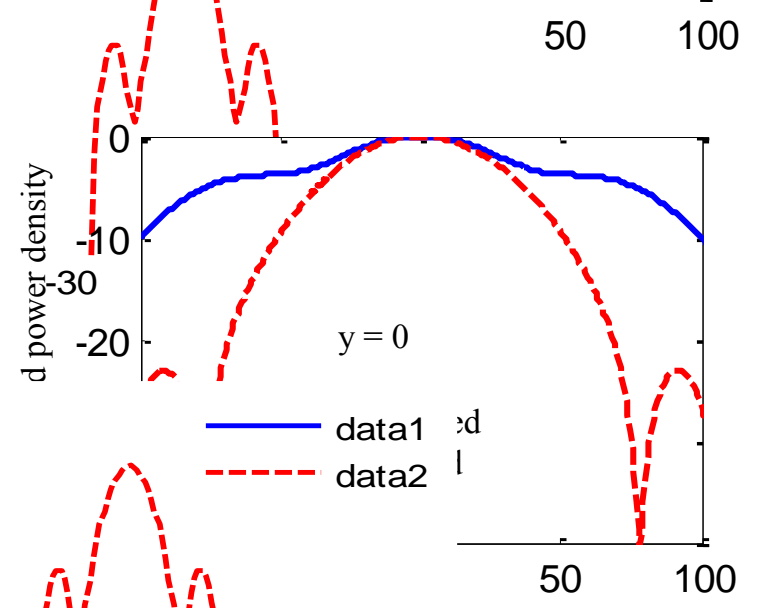

Im)

ower density along the $0 \mathrm{~mm}$ for $\mathrm{FF}$-focused ransmitarray from the anßona apeiture $(B) 0 x=0.6(b) y=90$.

\section{Design of dual- focused (FF/NF) transmitarray design}

In order to have a single structure transmitarray with dualfocused capability the chess-board unit-cell element arrangement is employed. The new single structure works in the FF- and NF-focused at the same time with high efficiency. The new design idea depends on rearranging the unit-cell elements successively using the pervious FF- and NF-focused transmitarrays to get the single structure with dual-focused. Principle of chess-board design for dualfocused (FF/NF) transmitarray design is presented in Fig. 8. Table 2 shows the phase distributions and corresponding hole radii for first quadrant of the FF/NF-Dual-focused transmitarray. The 3-D view of the normalized power density in the transverse plane (x-y plane) at a distance $\mathrm{R}_{\mathrm{o}}=$ $310 \mathrm{~mm}$ is shown in Fig.9a. The contour plot of the normalized power density in the $\mathrm{x}$-y plane for the dual-focus transmitarray at a distance $\mathrm{R}_{\mathrm{o}}=310 \mathrm{~mm}$ is shown in Fig.9b. The contours of the power density are closer to each other with $-10 \mathrm{~dB}$ spot area of $63 \mathrm{~mm} \times 60 \mathrm{~mm}$. The E-plane and H-plane radiation patterns for $13 \times 13$ dual-focused transmitarray antennas at frequency $10 \mathrm{GHz}$ compared with others transmitarrays planes are shown in Fig. 10. The dualfocused transmitarray introduces a maximum gain of $21 \mathrm{~dB}$ 
with SLL of $-13.4 \mathrm{~dB} /-13.9 \mathrm{~dB}$ and HPBW of 8.3/8.9 degrees in the E-plane/H-plane. The gain variations versus frequency for $13 \times 13 \quad$ FF-focused transmitarray, NF-focused transmitarray, and dual-focused transmitarray antennas are shown in Fig. 11. Figure 12 shows the distribution of the normalized power density for FF-, NF-focused, and dualfocus transmitarrays for in $\mathrm{x}-\mathrm{y}$ plane. The dual-focused transmitarray introduces an intermediate performance between the FF-focused transmitarray and the NF-focused transmitarray using the single structure.

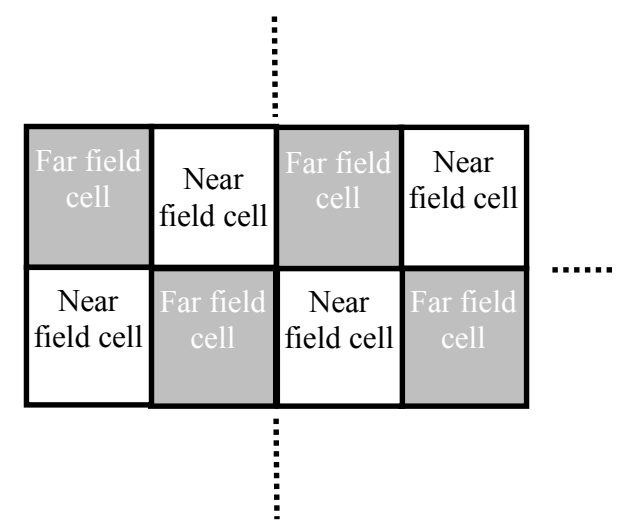

Figure 8: Principle of chess board plan for dual focus (FF/NF) transmitarray design.

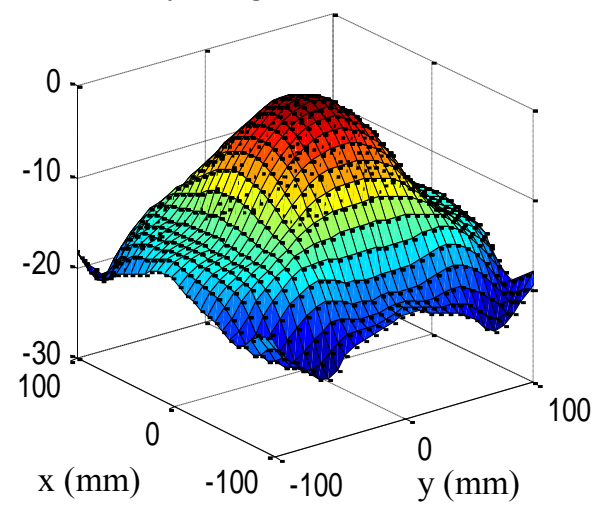

(a)

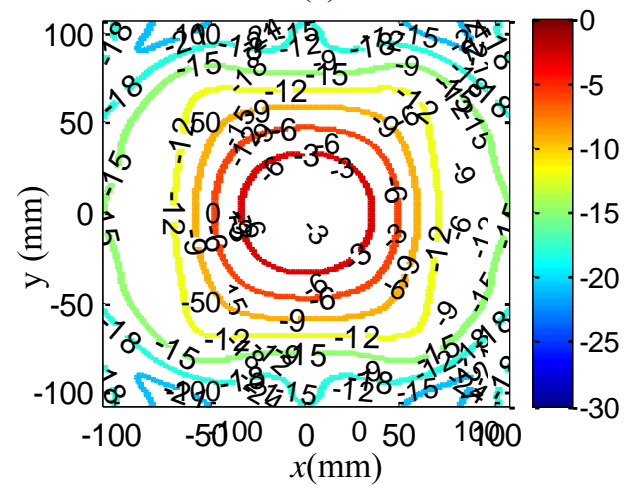

(b)

Figure 9: (a) A 3-D plot of the simulated normalized power density of $13 \times 13$ dual-focused transmitarray. (b) A contour plot of the simulated normalized power density of for the dual-focused transmitarray in $\mathrm{x}-\mathrm{y}$ plane at $\mathrm{R}_{\mathrm{o}}=310 \mathrm{~mm}$.
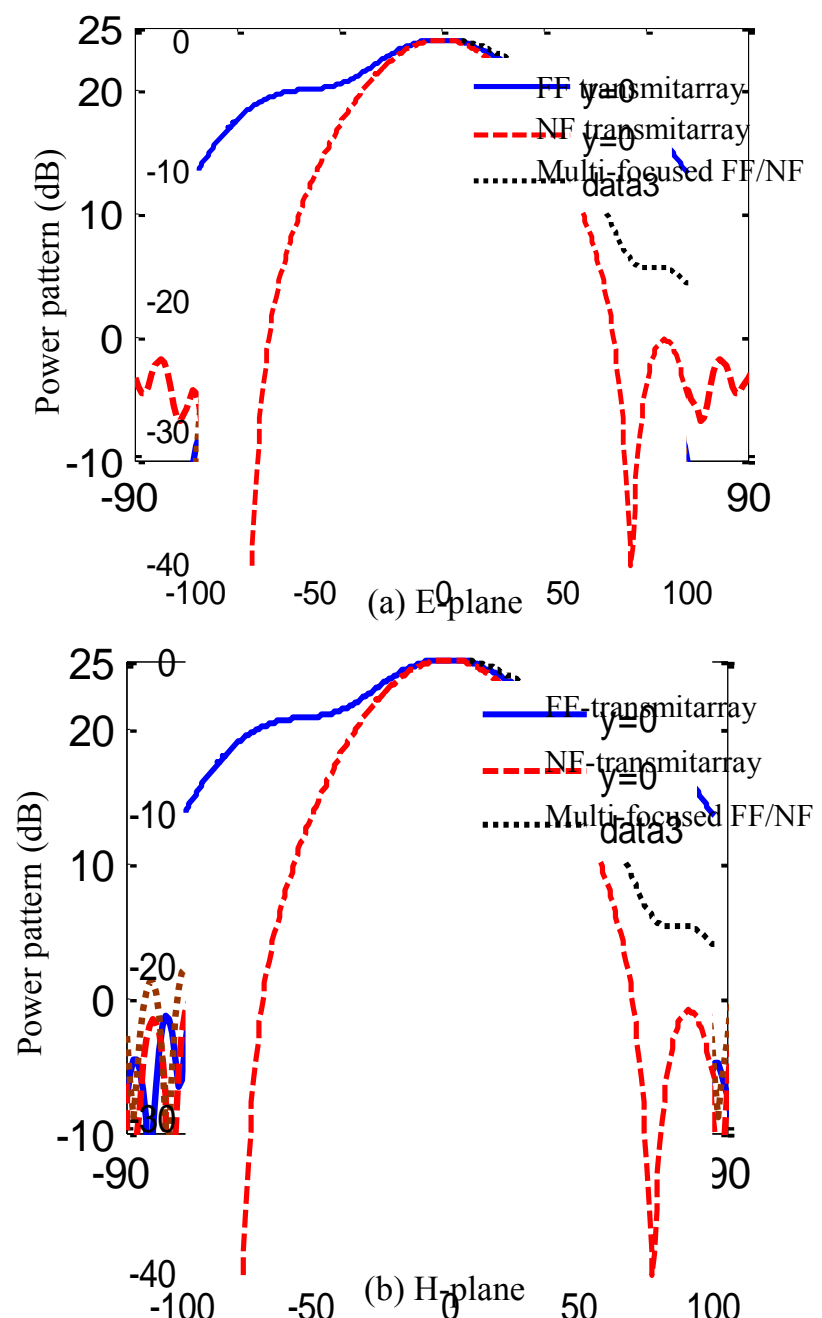

Figure 10: The E-plane and H-plane radiation patterns variations versus the elevation angle for FF-focused transmitarray, NF-focused transmitarray, and dual-focused transmitarray, at $\mathrm{F} / \mathrm{D}=0.9, \mathrm{R}_{\mathrm{o}}=310 \mathrm{~mm}$, and frequency 10 $\mathrm{GHz}$.

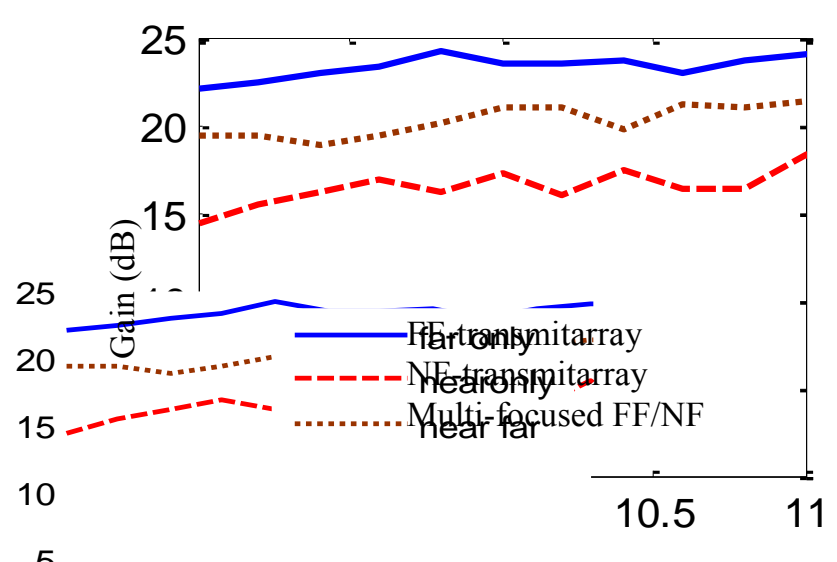

Frequency $(\mathrm{GHz})$

$0_{9}$ igure $b^{1} \cdot 5^{\text {the varjations }}$ it the gaip versus frequency for FF-focused transmitarray, NF-focused transmitarray, and dual-focused transmitarray at $\mathrm{F} / \mathrm{D}=0.9, \mathrm{R}_{\mathrm{o}}=310 \mathrm{~mm}$, and frequency $10 \mathrm{GHz}$. 


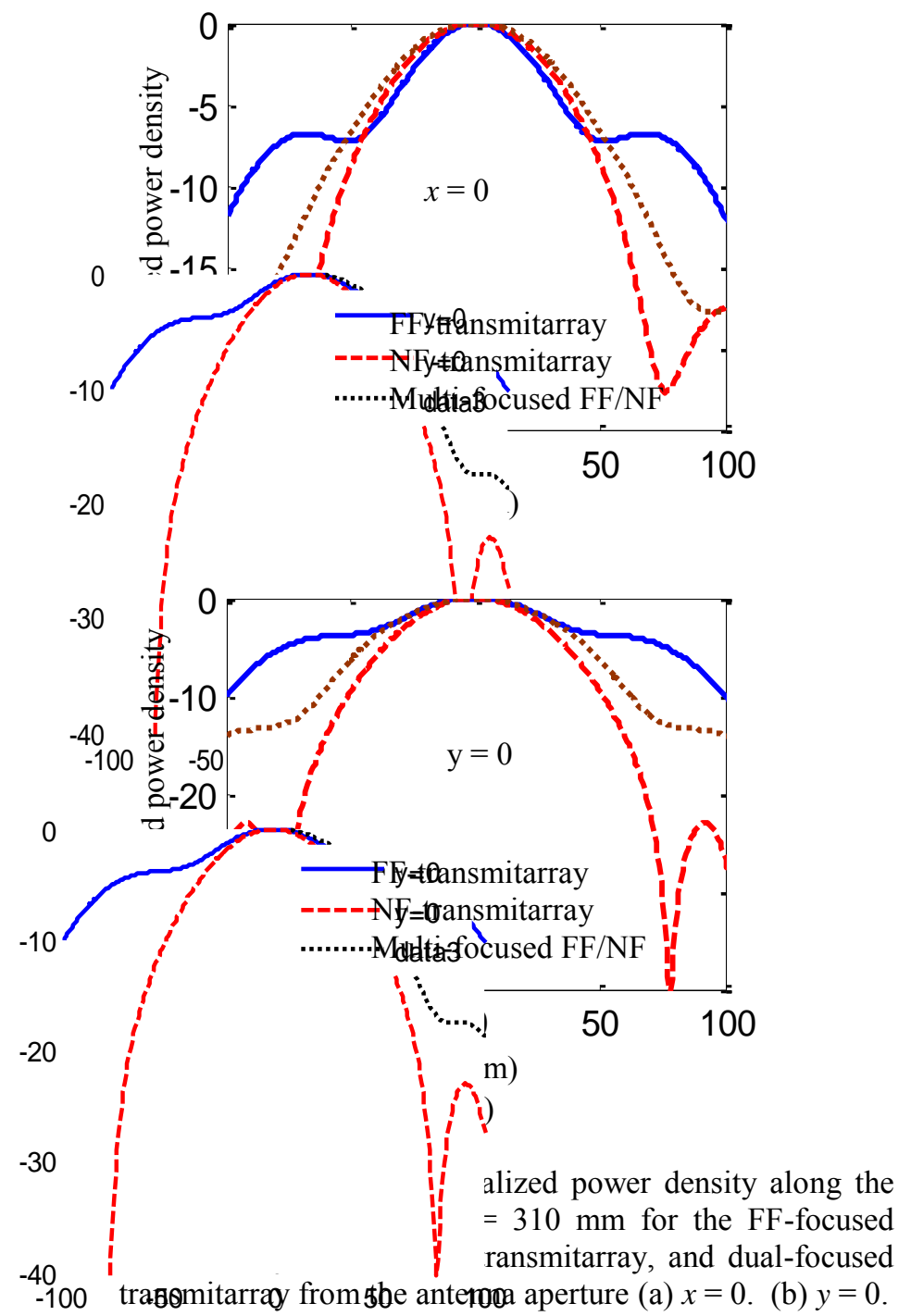

\section{Design of NF/ NF and FF/FF dual- focused transmitarray}

The previous concept is applied to obtain dual-focused in the near field region or dual-direction beams in the far field region. The design depends on the chess-board unit-cell element arrangement. The arrangement of the cells depends on the arrangement of the cells at different two distances in the Fresnel zone at $R_{0}=310 \mathrm{~mm}$ and $R_{0}=347 \mathrm{~mm}$ from the antenna aperture. Table 3 shows the phase distributions and corresponding hole radii for first quadrant of the NF/NFDual-focused transmitarray. The contour plot of the normalized power density in the $x-y$ plane for the NF/NFdual-focused transmitarray is shown in Fig. 13. The contours of the power density for $\mathrm{R}_{\mathrm{o} 1}=310 \mathrm{~mm}$ with $-10 \mathrm{~dB}$ spot area of $48 \mathrm{~mm} \times 45 \mathrm{~mm}$ are shown in Fig.13a. The contours of the power density for $\mathrm{R}_{02}=347 \mathrm{~mm}$ with $-10 \mathrm{~dB}$ spot area of $57 \mathrm{~mm} \times 50 \mathrm{~mm}$ are shown in Fig. 13b. Design for FF/FF dual-focused transmitarray depends on rearranged for the cells in the array to get two beams at different angles $\left(\theta=20^{\circ}\right.$ and $\theta=-20^{\circ}$ ) using single structure. The chess-board design for FF/FF dual-focused transmitarray is the same as previous one except takes cell at $\theta=20^{\circ}$ and the follow cell at $\theta=$ $20^{\circ}$ and then interchange the sequence to start with $\theta=-20^{\circ}$. Table 4 shows the phase distributions and corresponding hole radii for first half of the dual-direction beams transmitarray. The gain for $\theta=20^{\circ}$ is $15 \mathrm{~dB}$ and for $\theta=-20^{\circ}$ is $17 \mathrm{~dB}$. The $3 \mathrm{D}$ power pattern of dual beam transmitarray in the same structure is shown in Fig. 14. The HPBW is $8.6^{\circ}$ and $8.5^{\circ}$ for $\theta=20^{\circ}$ and $\theta=-20^{\circ}$, respectively.

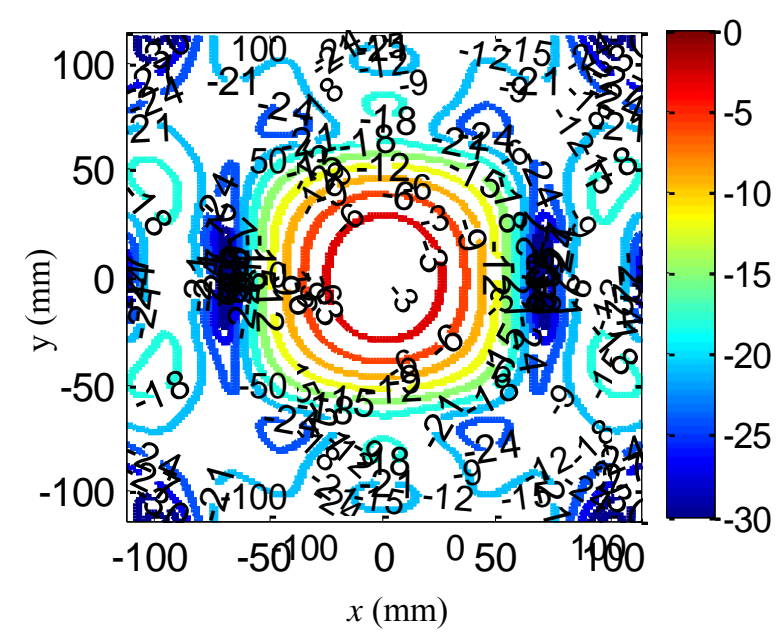

(a) $\mathrm{R}_{\mathrm{o} 1}=310 \mathrm{~mm}$

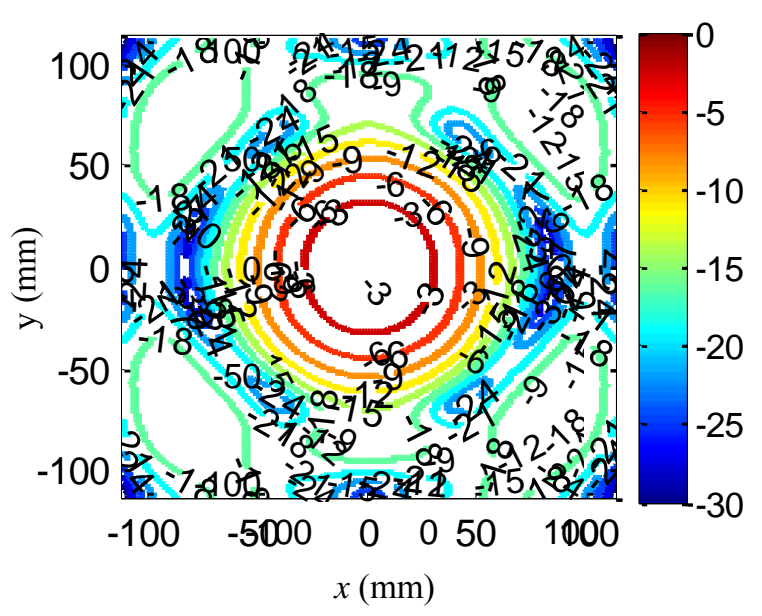

(b) $\mathrm{R}_{\mathrm{o} 2}=347 \mathrm{~mm}$

Figure 13: A contour plot of the simulated normalized power density of for the dual-focused transmitarray in a plane at (a) $\mathrm{R}_{\mathrm{o} 1}=310 \mathrm{~mm}$ and (b) $\mathrm{R}_{\mathrm{o} 2}=347 \mathrm{~mm}$. 
Table 2: The phase shift and the corresponding hole radius for FF/NF transmitarray (first quadrant).

\begin{tabular}{|c|c|c|c|c|c|c|}
\hline $306.00^{\circ}$ & $313.67^{\circ}$ & $353.92^{\circ}$ & $14.12^{\circ}$ & $134.71^{\circ}$ & $130.24^{\circ}$ & $360.38^{\circ}$ \\
$3.64 \mathrm{~mm}$ & $3.66 \mathrm{~mm}$ & $3.74 \mathrm{~mm}$ & $1.17 \mathrm{~mm}$ & $2.62 \mathrm{~mm}$ & $2.58 \mathrm{~mm}$ & $0.26 \mathrm{~mm}$ \\
\hline $313.67^{\circ}$ & $330.02^{\circ}$ & $344.11^{\circ}$ & $64.86^{\circ}$ & $72.94^{\circ}$ & $248.86^{\circ}$ & $213.61^{\circ}$ \\
$3.66 \mathrm{~mm}$ & $3.72 \mathrm{~mm}$ & $3.74 \mathrm{~mm}$ & $2.05 \mathrm{~mm}$ & $2.12 \mathrm{~mm}$ & $3.43 \mathrm{~mm}$ & $3.29 \mathrm{~mm}$ \\
\hline $353.92^{\circ}$ & $344.11^{\circ}$ & $41.34^{\circ}$ & $43.73^{\circ}$ & $180.70^{\circ}$ & $158.36^{\circ}$ & $404.29^{\circ}$ \\
$3.74 \mathrm{~mm}$ & $3.74 \mathrm{~mm}$ & $1.79 \mathrm{~mm}$ & $1.82 \mathrm{~mm}$ & $3.06 \mathrm{~mm}$ & $2.85 \mathrm{~mm}$ & $1.83 \mathrm{~mm}$ \\
\hline $14.12^{\circ}$ & $64.86^{\circ}$ & $43.73^{\circ}$ & $157.76^{\circ}$ & $130.24^{\circ}$ & $338.27^{\circ}$ & $267.59^{\circ}$ \\
$1.17 \mathrm{~mm}$ & $2.05 \mathrm{~mm}$ & $1.82 \mathrm{~mm}$ & $2.84 \mathrm{~mm}$ & $2.58 \mathrm{~mm}$ & $3.74 \mathrm{~mm}$ & $3.50 \mathrm{~mm}$ \\
\hline $134.71^{\circ}$ & $72.94^{\circ}$ & $180.70^{\circ}$ & $130.24^{\circ}$ & $316.07^{\circ}$ & $240.75^{\circ}$ & $533.81^{\circ}$ \\
$2.62 \mathrm{~mm}$ & $2.12 \mathrm{~mm}$ & $3.06 \mathrm{~mm}$ & $2.58 \mathrm{~mm}$ & $3.67 \mathrm{~mm}$ & $3.40 \mathrm{~mm}$ & $3.00 \mathrm{~mm}$ \\
\hline $130.24^{\circ}$ & $248.86^{\circ}$ & $158.36^{\circ}$ & $338.27^{\circ}$ & $240.75^{\circ}$ & $512.45^{\circ}$ & $12.12^{\circ}$ \\
$2.58 \mathrm{~mm}$ & $3.43 \mathrm{~mm}$ & $2.85 \mathrm{~mm}$ & $3.74 \mathrm{~mm}$ & $3.40 \mathrm{~mm}$ & $2.79 \mathrm{~mm}$ & $1.10 \mathrm{~mm}$ \\
\hline $360.38^{\circ}$ & $213.61^{\circ}$ & $404.29^{\circ}$ & $267.59^{\circ}$ & $533.81^{\circ}$ & $12.12^{\circ}$ & $382.88^{\circ}$ \\
$0.26 \mathrm{~mm}$ & $3.29 \mathrm{~mm}$ & $1.83 \mathrm{~mm}$ & $3.50 \mathrm{~mm}$ & $3.00 \mathrm{~mm}$ & $1.10 \mathrm{~mm}$ & $1.42 \mathrm{~m}$ \\
\hline
\end{tabular}

Table 3: The phase shift and the corresponding hole radius for NF/NF transmitarray (first quadrant).

\begin{tabular}{|c|c|c|c|c|c|c|}
\hline $306^{\circ}$ & $317.56^{\circ}$ & $353.92^{\circ}$ & $48.99^{\circ}$ & $134.71^{\circ}$ & $226.4^{\circ}$ & $360.38^{\circ}$ \\
$3.64 \mathrm{~mm}$ & $3 \mathrm{~mm}$ & $3.74 \mathrm{~mm}$ & $1.94 \mathrm{~mm}$ & $2.62 \mathrm{~mm}$ & $3.39 \mathrm{~mm}$ & $0.26 \mathrm{~mm}$ \\
\hline $317.56^{\circ}$ & $330.02^{\circ}$ & $363.52^{\circ}$ & $64.86^{\circ}$ & $138.56^{\circ}$ & $248.86^{\circ}$ & $355.15^{\circ}$ \\
$3.68 \mathrm{~mm}$ & $3.72 \mathrm{~mm}$ & $0.69 \mathrm{~mm}$ & $2.05 \mathrm{~mm}$ & $2.73 \mathrm{~mm}$ & $3.43 \mathrm{~mm}$ & $1.06 \mathrm{~mm}$ \\
\hline $353.92^{\circ}$ & $363.52^{\circ}$ & $41.34^{\circ}$ & $94^{\circ}$ & $180.7^{\circ}$ & $269.7^{\circ}$ & $404.29^{\circ}$ \\
$3.74 \mathrm{~mm}$ & $0.69 \mathrm{~mm}$ & $1.79 \mathrm{~mm}$ & $2.34 \mathrm{~mm}$ & $3.06 \mathrm{~mm}$ & $3.56 \mathrm{~mm}$ & $1.83 \mathrm{~mm}$ \\
\hline $48.99^{\circ}$ & $64.86^{\circ}$ & $94^{\circ}$ & $157.76^{\circ}$ & $226.4^{\circ}$ & $338.27^{\circ}$ & $439.13^{\circ}$ \\
$1.94 \mathrm{~mm}$ & $2.05 \mathrm{~mm}$ & $2.34 \mathrm{~mm}$ & $2.84 \mathrm{~mm}$ & $3.39 \mathrm{~mm}$ & $3.74 \mathrm{~mm}$ & $2.33 \mathrm{~mm}$ \\
\hline $134.71^{\circ}$ & $138.56^{\circ}$ & $180.7^{\circ}$ & $226.4^{\circ}$ & $316.07^{\circ}$ & $397.32^{\circ}$ & $533.81^{\circ}$ \\
$2.62 \mathrm{~mm}$ & $2.73 \mathrm{~mm}$ & $3.06 \mathrm{~mm}$ & $3.39 \mathrm{~mm}$ & $3.67 \mathrm{~mm}$ & $1.96 \mathrm{~mm}$ & $3.00 \mathrm{~mm}$ \\
\hline $226.4^{\circ}$ & $248.86^{\circ}$ & $269.7^{\circ}$ & $338.27^{\circ}$ & $397.32^{\circ}$ & $512.45^{\circ}$ & $243.03^{\circ}$ \\
$3.39 \mathrm{~mm}$ & $3.43 \mathrm{~mm}$ & $3.56 \mathrm{~mm}$ & $3.74 \mathrm{~mm}$ & $1.96 \mathrm{~mm}$ & $2.79 \mathrm{~mm}$ & $3.51 \mathrm{~mm}$ \\
\hline $360.38^{\circ}$ & $355.15^{\circ}$ & $404.29^{\circ}$ & $439.13^{\circ}$ & $533.81^{\circ}$ & $243.03^{\circ}$ & $382.88^{\circ}$ \\
$0.26 \mathrm{~mm}$ & $1.06 \mathrm{~mm}$ & $1.83 \mathrm{~mm}$ & $2.33 \mathrm{~mm}$ & $3 \mathrm{~mm}$ & $3.51 \mathrm{~mm}$ & $1.42 \mathrm{~mm}$ \\
\hline
\end{tabular}

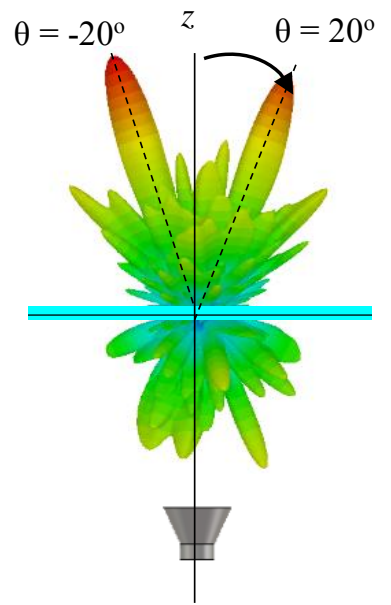

Figure 14: The 3D power pattern of dual beam transmitarray in the same structure. 
Table 4: The phase shift and the corresponding hole radius for dual beam transmitarray (first half).

\begin{tabular}{|c|c|c|c|c|c|c|}
\hline $\begin{array}{l}216.16^{\circ} \\
3.3 \mathrm{~mm} \\
\end{array}$ & $\begin{array}{l}204.23^{\circ} \\
3.24 \mathrm{~mm}\end{array}$ & $\begin{array}{c}243.38^{\circ} \\
3.41 \mathrm{~mm} \\
\end{array}$ & $\begin{array}{c}258.22^{\circ} \\
3.47 \mathrm{~mm} \\
\end{array}$ & $\begin{array}{l}323.25^{\circ} \\
3.7 \mathrm{~mm}\end{array}$ & $\begin{array}{c}2.74^{\circ} \\
0.44 \mathrm{~mm} \\
\end{array}$ & $\begin{array}{c}90.92^{\circ} \\
2.27 \mathrm{~mm}\end{array}$ \\
\hline $182.43^{\circ}$ & $85.13^{\circ}$ & $210.55^{\circ}$ & $140.87^{\circ}$ & $292.94^{\circ}$ & $248.56^{\circ}$ & $64.3^{\circ}$ \\
\hline $3.08 \mathrm{~mm}$ & $2.23 \mathrm{~mm}$ & $3.28 \mathrm{~mm}$ & $2.67 \mathrm{~mm}$ & $3.59 \mathrm{~mm}$ & $3.43 \mathrm{~mm}$ & $2.05 \mathrm{~mm}$ \\
\hline $311.93^{\circ}$ & $186.69^{\circ}$ & $340.86^{\circ}$ & $243.99^{\circ}$ & $65.49^{\circ}$ & $354.5^{\circ}$ & $200.13^{\circ}$ \\
\hline $3.66 \mathrm{~mm}$ & $3.12 \mathrm{~mm}$ & $3.74 \mathrm{~mm}$ & $3.41 \mathrm{~mm}$ & $2.06 \mathrm{~mm}$ & $3.74 \mathrm{~mm}$ & $3.22 \mathrm{~mm}$ \\
\hline $189.44^{\circ}$ & $206.26^{\circ}$ & $219.04^{\circ}$ & $264.88^{\circ}$ & $305.56^{\circ}$ & $17.74^{\circ}$ & $82.91^{\circ}$ \\
\hline $3.15 \mathrm{~mm}$ & $3.2 \mathrm{~mm}$ & $3.32 \mathrm{~mm}$ & $3.49 \mathrm{~mm}$ & $3.64 \mathrm{~mm}$ & $1.27 \mathrm{~mm}$ & $2.21 \mathrm{~mm}$ \\
\hline $99.67^{\circ}$ & $220.99^{\circ}$ & $129.79^{\circ}$ & $280.61^{\circ}$ & $217.73^{\circ}$ & $35.24^{\circ}$ & $357.13^{\circ}$ \\
\hline $2.34 \mathrm{~mm}$ & $3.32 \mathrm{~mm}$ & $2.58 \mathrm{~mm}$ & $3.55 \mathrm{~mm}$ & $3.31 \mathrm{~mm}$ & $1.7 \mathrm{~mm}$ & $3.74 \mathrm{~mm}$ \\
\hline $252.11^{\circ}$ & $22.89^{\circ}$ & $282.55^{\circ}$ & $83.13^{\circ}$ & $11.38^{\circ}$ & $198.87^{\circ}$ & $152.05^{\circ}$ \\
\hline $3.45 \mathrm{~mm}$ & $1.42 \mathrm{~mm}$ & $3.56 \mathrm{~mm}$ & $2.22 \mathrm{~mm}$ & $1.06 \mathrm{~mm}$ & $3.21 \mathrm{~mm}$ & $2.79 \mathrm{~mm}$ \\
\hline $306^{\circ}$ & $313.68^{\circ}$ & $336.55^{\circ}$ & $14.13^{\circ}$ & $65.68^{\circ}$ & $130.25^{\circ}$ & $206.78^{\circ}$ \\
\hline $3.64 \mathrm{~mm}$ & $3.66 \mathrm{~mm}$ & $3.74 \mathrm{~mm}$ & $1.17 \mathrm{~mm}$ & $2.06 \mathrm{~mm}$ & $2.58 \mathrm{~mm}$ & $3.26 \mathrm{~mm}$ \\
\hline $15.24^{\circ}$ & $259.77^{\circ}$ & $45.68^{\circ}$ & $320^{\circ}$ & $134.51^{\circ}$ & $75.75^{\circ}$ & $275.18^{\circ}$ \\
\hline $1.21 \mathrm{~mm}$ & $3.47 \mathrm{~mm}$ & $1.85 \mathrm{~mm}$ & $3.69 \mathrm{~mm}$ & $2.62 \mathrm{~mm}$ & $2.15 \mathrm{~mm}$ & $3.53 \mathrm{~mm}$ \\
\hline $213.42^{\circ}$ & $107.24^{\circ}$ & $243.54^{\circ}$ & $166.86^{\circ}$ & $331.48^{\circ}$ & $281.49^{\circ}$ & $110.87^{\circ}$ \\
\hline $3.29 \mathrm{~mm}$ & $2.4 \mathrm{~mm}$ & $3.41 \mathrm{~mm}$ & $2.39 \mathrm{~mm}$ & $3.72 \mathrm{~mm}$ & $3.55 \mathrm{~mm}$ & $2.42 \mathrm{~mm}$ \\
\hline $198.82^{\circ}$ & $196.88^{\circ}$ & $228.42^{\circ}$ & $255.49^{\circ}$ & $314.94^{\circ}$ & $8.36^{\circ}$ & $92.29^{\circ}$ \\
\hline $3.21 \mathrm{~mm}$ & $3.2 \mathrm{~mm}$ & $3.36 \mathrm{~mm}$ & $3.46 \mathrm{~mm}$ & $3.67 \mathrm{~mm}$ & $0.89 \mathrm{~mm}$ & $2.29 \mathrm{~mm}$ \\
\hline $179.42^{\circ}$ & $219.19^{\circ}$ & $208.35^{\circ}$ & $16.5^{\circ}$ & $292.98^{\circ}$ & $127^{\circ}$ & $67.62^{\circ}$ \\
\hline $3.06 \mathrm{~mm}$ & $3.68 \mathrm{~mm}$ & $3.27 \mathrm{~mm}$ & $1.24 \mathrm{~mm}$ & $3.59 \mathrm{~mm}$ & $2.56 \mathrm{~mm}$ & $2.08 \mathrm{~mm}$ \\
\hline $78.07^{\circ}$ & $189.49^{\circ}$ & $106.19^{\circ}$ & $245.23^{\circ}$ & $188.58^{\circ}$ & $352.92^{\circ}$ & $319.94^{\circ}$ \\
\hline $2.18 \mathrm{~mm}$ & $3.15 \mathrm{~mm}$ & $2.39 \mathrm{~mm}$ & $3.42 \mathrm{~mm}$ & $3.14 \mathrm{~mm}$ & $3.74 \mathrm{~mm}$ & $3.68 \mathrm{~mm}$ \\
\hline $179.39^{\circ}$ & $222.99^{\circ}$ & $224.62^{\circ}$ & $276.98^{\circ}$ & $304.49^{\circ}$ & $21.5^{\circ}$ & $72.16^{\circ}$ \\
\hline $3.2 \mathrm{~mm}$ & $3.33 \mathrm{~mm}$ & $3.34 \mathrm{~mm}$ & $3.54 \mathrm{~mm}$ & $3.63 \mathrm{~mm}$ & $1.39 \mathrm{~mm}$ & $2.12 \mathrm{~mm}$ \\
\hline
\end{tabular}

\section{Conclusion}

The paper introduces a single transmitarray antenna structure with dual-focus using the chess-board arrangement. The dual-focus of the transmitarray in near-field and a dual-beam directions in the far-field are designed. The transmitarray consists of $13 \times 13$ unit-cell elements made of a perforated dielectric sheet. Different transmitarrays with dual-focus in the $\mathrm{NF} / \mathrm{NF}, \mathrm{FF} / \mathrm{FF}, \mathrm{NF} / \mathrm{FF}$ and $\mathrm{FF} / \mathrm{NF}$ regions are designed using the chess-board arrangement. The FF/NF-focused transmitarray introduces a maximum gains of 23.45 $\mathrm{dB} / 17.26 \mathrm{~dB}$ with a side lobe level of $-15.7 \mathrm{~dB} /-8 \mathrm{~dB}$ in the E-/H-plane. In the same structure the array produced power density closer to each other with $-10 \mathrm{~dB}$ spot area of $63 \times 60 \mathrm{~mm}^{2}$ at a distance $\mathrm{R}_{0}=310 \mathrm{~mm}$. The NF/NF transmitarray with power focused in two near field distances at $\mathrm{R}_{\mathrm{o} 1}=310 \mathrm{~mm}$ and $\mathrm{R}_{\mathrm{o} 2}=347 \mathrm{~mm}$ is designed. Finally, dualbeam transmitarray is proposed to obtain two beams in different directions with angles $20^{\circ}$ and $-20^{\circ}$ in the same structure using the chess-board arrangement. The maximum gains for beam at $\theta=20^{\circ}$ is $15 \mathrm{~dB}$ and for the beam at $\theta=-$ $20^{\circ}$ is $17 \mathrm{~dB}$.

\section{References}

[1] O. Yurduseven, Compact parabolic reflector antenna design with cosecant-squared radiation pattern, Microwaves, Radar and Remote Sensing Symposium, Kiev, Ukraine, pp. 382-385, August 2011.
[2] G. M. Rebeiz, K. J. Koh, Tiku Yu, D. Kang, C. Y. Kim, Y. Atesal, B. Cetinoneri, S. Y. Kim, and D. Shin, Highly dense microwave and millimeter wave phased array $\mathrm{T} / \mathrm{R}$ modules and butler matrices using CMOS and SiGe RFICs, IEEE International Symposium on, Phased Array Systems and Technology (ARRAY), Boston, Massachusetts, USA, pp. 245-249, October 2010.

[3] M. Ruphuy, Z. Ren, and O. M. Ramahi, Flat far field lenses and reflectors, Progress In Electromagnetics Research M, (PIER M), vol.34, pp.163-170, 2014.

[4] J. Huang and J. A. Encinar, Reflectarray Antennas, IEEE Press, John Wiley and Sons, New Jersey, USA, 2008.

[5] S. H. Zainud-Deen, W. M. Hassen, and H. A. Malhat, Investigation into the effect of solar cells on the DRA reflectarray/transmitarray antenna design, $32^{\text {nd }}$ National Radio Science Conference (NRSC), $6^{\text {th }}$ of October City, Egypt, pp. 1-8, March 2015.

[6] S. H. Zainud-Deen, S. M. Gaber, H. A. Malhat, and K. H. Awadalla, Perforated transmitaray-enhanced circularly polarized antenna for high-gain multi-beam radiation, International Symposium on Antennas and Propagation (ISAP 2013), Nanjing, China, pp. 484-487, October 2013.

[7] M. K. Al-Nuaimi and W. Hong, Discrete dielectric reflectarray and lens for E-band with different feed, IEEE Antennas and Wireless Propagat. Letters, vol.13, pp. 947-950, March 2014. 
[8] S. H. Zainud-Deen, N. El-Shalaby, S. M. Gaber, H. A. Malhat, and K. H. Awadalla, Reflectarrays mounted on or embedded in cylindrical or spherical surfaces, Middel East Conference on Antennas and Propagat. (MECAP 2012), Cairo, Egypt, pp.1-6, December 2012.

[9] L. Dussopt, H. Kaouach, J. Lanteri, and R. Sauleau, Circularly-polarized discrete lens antennas in $60-\mathrm{GHz}$ band, Radio engineering, vol. 20, no.4, pp. 733-738, December 2011.

[10] S. M. Gaber, Analysis and Design of Reflectarrays/Transmitarrays Antennas, Ph.D Thesis, Faculty of Electronic Engineering, Minoufia University, Menouf, Egypt, 2013.

[11] S. H. Zainud-Deen, W. M. Hassen, H. A. Malhat, and K. H. Awadalla, Radiation characteristics enhancement of dielectric resonator antenna using solid/discrete dielectric lens, Advanced Electromagnetics, vol. 4, no. 1, February 2015.

[12] J. Y. Lau and S. V. Hum, A wideband reconfigurable transmitarray element, IEEE Trans. Antennas Propagat., vol. 60, no. 3, pp. 1303-1311, March 2012.

[13] E. Eridl, K. Topalli, O. Zorlu, T. Toral, E. Yildirim, H. Kulah, and O. A. Civi, A reconfigurable microfluidic transmitarray unit cell, $7^{\text {th }}$ European Conference on Antennas and Propagat. (EUCAP), Gothenburg, Sweden, pp. 2957-2960, April 2013.

[14] A. H. Abdelrahman, P. Nayeri, A. Z. Elsherbeni, and F. Yang, Analysis and design of wideband transmitarray antennas with different unit-cell phase ranges, IEEE Antennas and propagat. Society International Symposium (APSURSI), Memphis, USA, pp. 1266-1267, July 2014.

[15] J. Venter, M. Pelouskova, Outcomes and complications of a multifocal toric intraocular lens with a surfaceembedded near section, Journal of Contaract \& Refractive Surgery, vol. 39, pp. 859-866, June 2013.

[16] R. Siragusa, P. Lemaître-Auger, and S. Tedjini, Tunable near-field focused circular phase-array antenna for 5.8-GHz RFID applications, IEEE Antennas and Wireless Propagat. Letters, vol. 10, pp. 33-36, March 2011.

[17] A. Buffi, P. Nepa, and G. Manara, Design criteria for near-field-focused planar arrays, IEEE Antennas Propag. Mag., vol. 54, no. 1, pp. 40-50, February 2012.

[18]F. Tofigh, J. Nourinia, M. N. Azarmanesh, and K. M. Khazaei, Near-field focused array microstrip planar antenna for medical applications, IEEE Antennas and Wireless Propagat. Letters, vol. 13, pp. 951-954, May 2014.

[19] K. D. Stephan, J. B. Mead, D. M. Pozar, L. Wang, and J. A. Pearce, A near field focused microstrip array for a radiometric temperature sensor, IEEE Trans. Antennas Propagat., vol. 55, no. 4, pp. 1199-1203, April 2007.

[20] A. Buffi, A. Serra, P. Nepa, G. Manara, and M. Luise, Near field focused microstrip arrays for gate access control systems, In Proc. IEEE Antennas Propag. Symp., Charleston, SC, USA, pp. 1-4, June 2009.
[21]M. Bogosanovic and A. G. Williamson, Microstrip antenna array with a beam focused in the near-field zone for application in noncontact microwave industrial inspection, IEEE Trans. Instrum. Meas., vol. 56, no. 6, pp. 2186-2195, December 2007.

[22] B. Shrestha, A. Elsherbeni, and L. Ukkonen, UHF RFID reader antenna for near-field and far-field operations, IEEE Antenna and Wireless Propag., vol. 10, pp. 12741277, November 2011.

[23] R. Siragusa, P. Lemaitre-Auger, and S. Tedjini, Near field focusing circular microstrip antenna array for RFID applications, In Proc. IEEE APSURSI, Charleston, SC, pp. 1-4, June 2009.

[24] S. H. Zainud-Deen, H. A. Malhat, K. H. Awadalla, $8 \times 8$ near-field focused circularly polarized cylindrical DRA array for RFID applications, The applied computational Electromagnetics (ACES), vol. 27, no. 1, pp. 42-48, 2012 .

[25] User's manual of CST Microwave Studio 2012.

[26] S. H. Zainud-Deen, S. M. Gaber, H. A. Malhat, and K. H. Awadalla, Cylindrical perforated transmitarrays, $2^{\text {nd }}$ Middle East Conf. on Antenna and Proagat. (MECAP), Egypt, pp. 1-7, December 2013.

[27] R. C. Hansen, Focal region characteristics of focused array antennas, IEEE Trans. Antennas Propagat., vol. 33, no. 12, 1328-1337, December 1985.

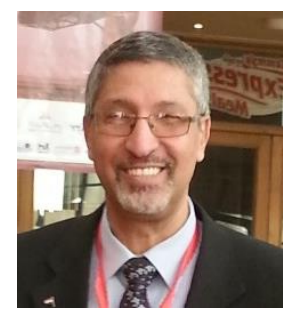

Saber Helmy Zainud-Deen: was born in Menouf, Egypt, on November 15, 1955. He received the B.Sc and M.Sc degrees from Menoufia University in 1973 and 1982 respectively, and the Ph.D degree in antenna engineering from Menoufia University, Egypt in 1988. He is currently a professor in the department of electrical and electronic engineering in the faculty of electronic engineering, Menoufia University, Egypt. His research interest at present include microtrip and leaky wave antennas, DRA, RFID, optimization techniques, FDFD and FDTD, scattering problems and barest cancer detection.

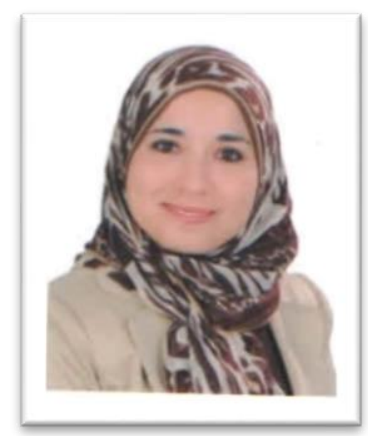

W. M. Hassan: was born in Shebien El-Kom, Menoufia, Egypt, on January 11, 1981. She received the B. Sc M. Sc degrees from Menoufia University in 2002 and 2010. She is currently assistant researcher in electronics research institute (ERI). Her research interest at FDFD, Scattering, breast cancer detection, chiral materials, metamaterials, DRA, transmitarray, reflectarray, solar cell, and graphene. 


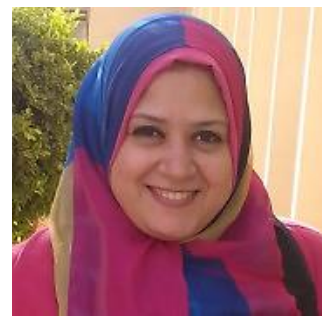

Hend Abd El-Azem Malhat: was

born in Menouf, Egypt, on December 12, 1982. She received the B. Sc and M. Sc degrees from Menoufia University in 2004 and 2007 respectively. She received her

Ph.D degree in Antenna

Engineering from Menoufia

University, Egypt 2011. She is currently an associated professor in the department of electrical and electronic engineering in the faculty of electronic engineering, Menoufia University, Egypt. Her research interest at present include Graphene antennas, plasma antennas, wavelets technique, transmitarray, reflectarray and RFID. 